\title{
Germany's Higher Education Cooperation in Africa between Aid and Trade ${ }^{1}$
}

\begin{abstract}
The following article is directed to summarise different types of cooperation between Germany and African institutions in respect of higher education (HE), especially focusing on the main German organisations operating as (co-)financed by state budgets. Suggesting the relevance of $\mathrm{HE}$ for African middle classes the position of African universities in international rankings are discussed. The author then suggests reflecting the specific traits and differences between 'Aid', 'Exchange', 'Cultural Diplomacy' and 'Trade' in education transfers across borders before presenting German government-backed institutions and their programmes towards HE in Africa according to these types of what is mostly called 'cooperation' or 'partnerships'. The article closes with some conclusions and the contextualisation of German HE policies into the broader scene of the HE transfer.
\end{abstract}

Keywords: international education transfer, international education policy, international cooperation, foreign cultural and educational policy, higher education rankings, international cooperation

\section{Zusammenfassung}

Im folgenden Aufsatz wird die Zusammenarbeit Deutschlands mit afrikanischen Ländern im Hochschulbereich, mit Blick auf die wichtigsten deutschen staatlichen oder wesentlich mit staatlichen Mitteln agierenden Organisationen, thematisiert. Vor dem Hintergrund der gewachsenen Bedeutung von Hochschulbildung für die afrikanischen Mittelklassen werden internationale Rankings hinsichtlich der Position afrikanischer Universitäten ausgewertet. Im weiteren Fortgang wird zunächst vorgeschlagen, sich der Spezifika und Unterschiede verschiedener Typen grenzüberschreitender Bildungstransfers gewahr zu werden, namentlich ,Hilfe', ,Austausch', ,Kulturelle Diplomatie und ,Handel'. Anschließend werden die wichtigen deutschen Akteure und ihre Programme, die meist unter Etiketten wie ,Zusammenarbeit' oder, Partnerschaft' firmieren, anhand dieser Typen vorgestellt und eingeordnet. In den abschlieBenden Folgerungen wird die deutsche Hochschulkooperation in größere Zusammenhänge des hochschulischen Bildungstransfers eingeordnet.
Keywords: internationaler Bildungstransfer, internationale Bildungspolitik, auswärtige Kultur-und Bildungspolitik, Hochschul-Rankings, internationale Kooperation

\section{The Challenge: Expansion and reputation of higher education in Africa}

Different from what one might expect - because there is a tendency to allocate the establishment of higher education in Africa to colonialism only - African initiatives to demand and install higher education (HE) date back already to the 19th century; but they were blocked by colonialism instead of being welcomed (Adick, 1989). Due to such colonial legacies, but also other factors like lack of resources and/or political will of ruling regimes, educational developments in most African countries and especially HE lagged behind global trends for long. But nowadays, HE has entered the agenda of Education for All, since even the UNESCO with its long impetus on basic education has come to suggest "six ways to ensure higher education leaves no one behind” (UNESCO, 2017, n. p.).

In recent years, $\mathrm{HE}$ in Africa seems to be attracting the interest of a growing African middle class (Melber, 2016) with two basic options to acquire 'academic capital': either to send their children to study abroad (outside Africa) or enrol them at a renowned HE institution at home or in an African country. German actors' interests in HE in Africa may also work both ways: either to attract and support African students to study in Germany, or to further African HE institutions or even set up 'German' institutions there. The growing importance of Africa in the international HE scene may well be illustrated by the fact that in 2016 the 10th "International Further \& Higher Education \& Research Conference" of "Education International" (which is the global non-governmental trade unions organisation of personnel working in education) took place in Africa (in Accra/Ghana) for the first time in its existence. This and other events bring HE in Africa to the surface of an international audience. 
As the UNESCO noted (2017, p. 2), HE providers have become more diverse with more private ones and more international providers acting alongside or in competition with national colleges and universities. If there is choice, there will be comparison and competition. Hence, HE institutions in Africa have now come to be listed in international university rankings. Notwithstanding general debates about the (non-)sense of rankings and league tables in education, the fact that HE institutions in Africa do appear after decades of absence from international league tables at least indicates growing international visibility and debate. In an online-survey among experts of the German Academic Exchange Service (DAAD) who work in the international dependencies of their organisation the interviewees stressed the importance of rankings especially as assets for entering into new HE cooperation schemes, for Master programmes and for scholarships (Burkart \& Wittersheim, 2017). ${ }^{2}$

Two rankings shall be taken as examples here: one which operates on the basis of popularity (uniRank ${ }^{\mathrm{TM}}$ ), the other one on the basis of achievements (QS Ranking) - comparing their data published in 2018. uniRank $^{\text {TM }}$ (formerly 4 International Colleges \& Universities or 4icu.org) is located in Australia and reviews about 13,000 Colleges and Universities world-wide, which are ranked by web popularity. Although the criterion of web popularity is widely criticised ${ }^{3}$ it might be quite relevant for Africa, since access to the internet has widely spread throughout Africa and surely outperforms e.g. any sending of brochures by ordinary mail. So future students, teachers, parents and advisors, do likely consult the web pages of HE institutions in search of information. Also, uniRank ${ }^{\mathrm{TM}}$ only focuses $\mathrm{HE}$ institutions which are officially recognized by national or regional bodies. They include at least four-year undergraduate degrees (Bachelor's Degrees) and/or postgraduate degrees (Master's and Doctoral Degrees) which "provide higher education courses mainly in a traditional face-to-face learning format delivered through on-site facilities" (https://www.4icu.org/about/; accessed 16.02.2018).

The 2018 ranking of the Top 200 Universities in Africa showed that the top ten positions were nearly exclusively hold by South African universities (cf. tab. 1). Also, if one looks at the first 20 ranks, the majority (13 from 20) are South African HE institutions. The ranking further discloses that some long established universities from a few other African countries - Kenya, Egypt and Nigerian institutions - are among the top 20 positions, with only one institution from Mozambique and one from Sudan. ${ }^{4}$ According to this ranking the distribution of $\mathrm{HE}$ by popularity is far from being evenly distributed across African countries. The ranking also includes foreign universities; among them the long-established American University of Cairo (number 10 in 2018), whereas the much younger German University of Cairo, inaugurated in 2003 subsidized by 10 Million Euros as part of a German government initiative to increase German transnational exports of $\mathrm{HE}$ to Africa (Adick, 2008, p. 183, 186), occupies rank 30, and the British University in Egypt rank 63 out of 200 African universities [https://www.4icu.org/top-universities-africa/; accessed 16.02.2018].
South African Universities (Ranks)

- University of Pretoria (1)

- University of Cape Town (2)

- University of Witwatersrand (3)

- University of KwaZulu-Natal (4)

- University of Johannesburg (5)

- University of Stellenbosch (6)

- North-West University (7)

- University of the Western Cape (8)

- Rhodes University (13)

- Universiteit van de Vrystaat (16)

- Cape Peninsula Univ. of Technology (18)

Universities in other African countries (Ranks)

- University of Nairobi, Kenya (9)

- American University of Cairo, Egypt (10)

- University of Lagos, Nigeria (11)

- Ahmado Bello University, Nigeria (12)

- Cairo University, Egypt (14)

- University of Ibadan, Nigeria (15)

- Univ. Eduardo Mondlane, Mozambique (17)

- University of Khartoum, Sudan (19)

- University of Nigeria, Nigeria (20)

Table 1:

The Top 20 Universities in Africa according to uniRank ${ }^{\mathrm{TM}}$ 2018; Source: own elaboration on the basis of 2018 data from uniRank $k^{\text {TM }}$

[https://www.4icu.org/top-universities-africal; accessed 16.02.2018]

QS University Ranking compares HE institutions according to achievement criteria. The 2018 ranking will be referred to [https:/www.topuniversities.com/university-rankings/ world-university-rankings/2018; accessed 17.02.2018]. This organisation offers world-wide rankings and regional rankings including a 'region' called BRICS - the rising economies of the world (Brazil, Russia, India, China, South Africa) - but no region called "Africa" [https://www.topuniversities.com/regional-rankings; accessed 17.02.2018]. But researchers can find a link to African Universities which states that 18 African universities were among the 1,000 universities of the 2018 ranking, most of which (but not all) are listed in the second half of the ranks (from rank 501 onwards), and most of which are located in South Africa [https://www.topuniversities.com/ university-rankings-articles/world-university-rankings/ top-universities-africa; accessed 17.02.2018].

Extracting the African universities in order of appearance in the original ranking of the 1,000 universities world-wide (cf. tab. 2), the QS University Ranking includes nine universities located in South Africa, and nine in other African countries, most of them in Egypt.

If one compares the two rankings (both for 2018), there are a lot of similarities, especially in respect of the dominance of South African universities in the first place and Egyptian in the second place, compared to the low entries from other African countries. What would this mean for international cooperation in $\mathrm{HE}$ ? It could mean very different and contrasting challenges - depending on the motives of the - possible foreign donor or investor in HE. If South Africa leads the ranks of African universities, this might as well attract the installation 
of non-profit, but high fees demanding or even profit seeking foreign university branches from the 'global North' as well as calling for development aid for countries whose HE systems are wanting. Because the HE system in South Africa is seemingly well reputed, foreign cultural and educational policies could try to attract especially South African students to study in their countries and possibly remain (e.g. in Europe) to fill open positions in the academically skilled labour market (e.g. doctors or ICT personnel). In contrast, however, the dearth of study opportunities for African youths in some African countries might also motivate governments, foundations, churches and others in the 'global North' to increase their scholarship programmes and other aid schemes directed to HE in Africa.

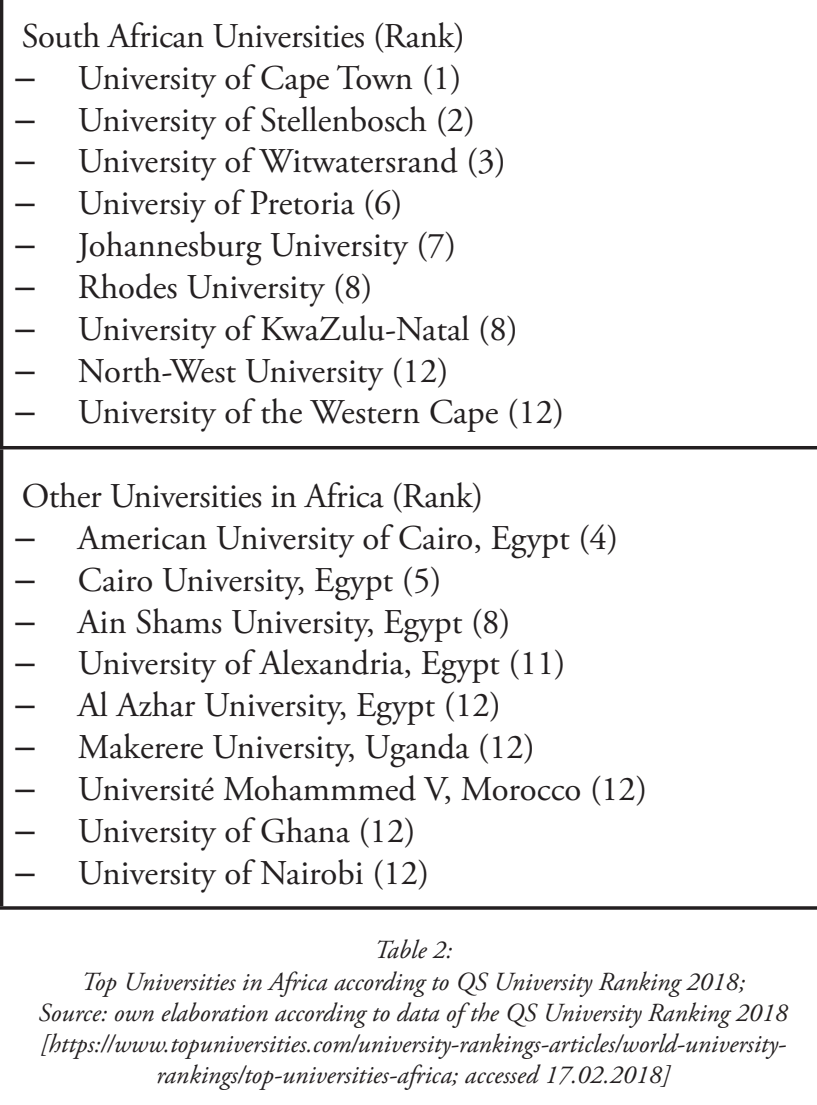

\section{What is meant by HE cooperation?}

First, it has to be clarified what is meant by 'higher education' (HE). Since long, in many countries including Germany, this term would have alluded to the idea of 'classical' universities. But in the meantime other institutions and terms have been created such as the 'Fachhochschulen', translated into English as 'universities of applied sciences', in Germany, or postsecondary polytechnics and academies. Problems of translating foreign terminology into national languages add to confusion, since an institution which exists in one country does not necessarily have a structural counterpart in another country. It is therefore eminent to reflect the terms in discussions and publications, as may be exemplified by a little episode (cf. Adick 2018b, p. 15): In a first press release of the German UNESCO Commission announcing the already-named UNESCO policy paper on "six ways to ensure higher education leaves no one behind”, the term 'higher education' was translated into the
German 'Hochschulbildung', which, however, was corrected in a second press release only about $2 \frac{1 / 2}{2}$ rs. afterwards to mean 'tertiäre Bildung', i.e. tertiary education, including a footnote to explain that 'tertiary education' includes advanced vocational and further education, which means Levels 5 to 8 of the ISCED (International Standard Classification of Education) in its version of the year 2011; i.e. short-cycle tertiary education (level 5), Bachelor's Degree or equivalent (level 6), Master's degree or equivalent (level 7) and Doctorate or equivalent (level 8). Reflecting such terminological details is eminent in any forms of international cooperation in higher education, because it cannot be taken for granted that all trainings and certificates, e.g. in realms such as nursing, management or technical studies, are equally allocated to 'tertiary' level institutions in every country.

"Cooperation" in education and other realms is often a 'catch-all' phrase for very diverse and even contradictory formats of 'connections' between persons and organisations. Everybody alludes to 'cooperate' with one another; who or which organisation would overtly declare in a website or a programme brochure to aspire to extract profit, exploit somebody, or influence her or him politically by the educational programme which is offered? From this observation stems the title of this article: "between aid \& trade". Instead of globally speaking of 'cooperation' or 'partnerships' this will be differentiated into four types which represent variations of 'international education transfer' (cf. fig. 1) which stands for the transnational mobility of educational ideas, reform concepts, personnel, finances and goods across national borders (cf. Adick, 2018a). It is supposed here that any cooperation or transfer also means interference into national and local $\mathrm{HE}$ policies from the outside and that all partnerships should be regarded as more or less overtly 'strategic'.

All variants apply cross-border activities with different types of actors, e.g.: individuals, governmental or non-governmental organisations, philanthropic foundations, churches, for profit enterprises, or national and international organisations, each of them acting according to their own motives and arrangements. Grosso modo "Aid" is associated with donations to recipients in need, such as schools that lack books or furniture, teachers without salaries, or ministries lacking finances for an education reform (Scheunpllug, Wenz \& Wirth, 2018). In contrast, "Cultural Diplomacy" means educational transfer across borders as part of the official foreign policy of a given country with foreign cultural institutes (e.g. Goethe and Confucius institutes) and foreign schools abroad as most obvious examples (Adick, 2016). "Exchange" alludes to formats of 'connections' that are encompassing 'true' vice versa cooperation, i.e. implying factual (and not just proclaimed) reciprocity like mutual visits and study semesters of students in partnership arrangements such as the ERASMUS scheme in the European Union (Feyen \& Krzaklewska, 2013) which has in the meantime been enlarged to reach out to non-European students including students from Africa by "ERASMUS + " Programmes. Contrastingly, "Trade" is applied to entrepreneurial types of international education transfer, meaning education as a business: Clients have to pay fees, which may be meant either to cover the costs of the provider or be overtly commercial and profit-seeking or a mix of both according to the strategic 


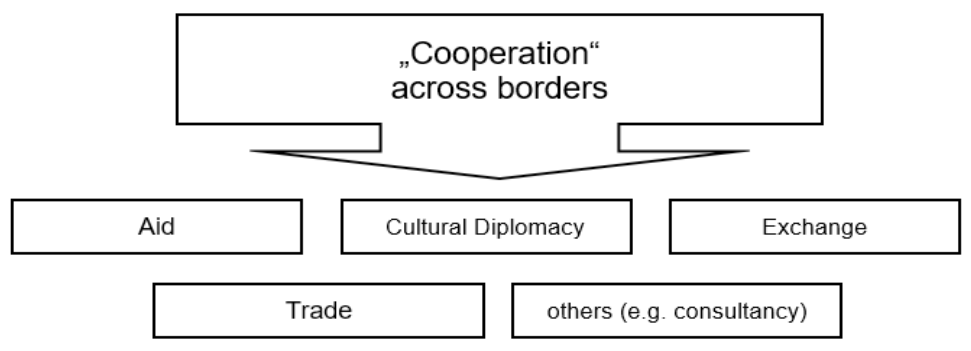

Figure 1: Types of international education transfer; Source: own elaboration

development of such 'education companies' (Adick, 2014). Even though it is not always easy to unanimously accord these types to specific programmes or institutions, it is suggested here that these four types of international education transfer may well serve to analyse motives and formats of existing German HE transfers in Africa as, in principle, also those of other countries (which, however, are not discussed here).

\section{German government-backed international higher education transfer}

The article will try to give an overview of German HE transfer according to the four types of cross-border relations discussed above. Main actors in this very complex scenery will be sketched, whereby special attention is given to important governmental institutions which regulate, finance and control, not least by giving incentives and issuing programmes to support $\mathrm{HE}$ transfer to African (or other) countries. In this article, therefore, the main focus lies on 'official' German actors and activities. $^{5}$

Considering "Aid" the German Federal Ministry of Cooperation and Development (BMZ) supports the SDGs (Sustainable Development Goals)/Agenda 2030 of the United Nations (BMZ, 2015). Education is targeted by the fourth SDG (cf. Adick, 2018b); whereby two points are relevant for $\mathrm{HE}$ transfer to Africa: the objective to ensure equal access also to tertiary education, including university (SDG 4.3) and the demand to increase numbers of scholarships for students from 'developing countries' (SDG 4.B). Africa has become the priority continent of German development 'aid' cooperationtype, working in about 32 (of the 54) African countries with about half of German bilateral funding going there. The BMZ (2014) declared a 'new Africa policy' condensed in ten points, one of which is directed towards 'prospects of Africa's youth' including training and youth exchange. The BMZ (2015) has also issued an "education strategy" which declares a growing focus on vocational and tertiary education including the support of the Pan African University and the spread of ICT in Africa. It offers additional 1.000 scholarships for Africa plus 7 bilateral graduate schools plus a Skills Initiative for Africa. Important to say, the BMZ is also the leading institution to cofund the numerous German non-state actors' projects in the so-called Third world considerably, like such ones from churches, foundations or NGOs. The total Federal Budget of BMZ (year 2017) amounted to: $€ 8,541$ Billion.

Among other German actors, the BMBF has also increased its activities directed to Africa parts of which turn out to be of the 'aid'-type. The first such strategy was issued for the years
2014-2018 (BMBF, 2017a). The recently renewed Africa strategy (BMBF, 2018) was headlined as "Creating Prospects!" and explicitly claims to be in line with the "Agenda 2063" of the African Union and its sector specific strategies. The BMBF supports some 'Maria Sibylla Merian International Centres for Advanced Studies in the Humanities and Social Sciences' in Africa, the first of which has been inaugurated at the University of Ghana, Legon in 2017 (BMBF, 2017b). German partner institutions are the University of Freiburg (coordinating), the German Historical Institute at Paris, the German Institute of Global and Area Studies (GIGA) in Hamburg and the Frankfurt and Konstanz Universities. Scientists of the various institutions and disciplines will collaborate in tackling mixed topics along migration and rural development, energy and resources in Africa.

The "Exchange"-type of cross-border relations is clearly connected to the long-established German Academic Exchange Service (DAAD). Looking at overall figures, Germany ranges among the top 5 for international students (after USA, GB, Australia \& France; 2013). But when comparing flows of foreign students both ways it needs to be stressed, however, that African students studying in Germany are by far outnumbering German students studying in Africa (22.900 Students from Africa in Germany [2015] vs. 800 Students from Germany in Africa [2013] (DAAD, 2016a). The top ten target countries of German HE institutional relations with Africa are (in absolute numbers and disregarding study subjects): Egypt (20), South Africa (17), Kenya (14); Ethiopia, Morocco, Tunisia, Rep. Congo, Tanzania, Uganda, Nigeria and Cameroon follow with lower numbers of officially recorded relations. There are special programmes like AGNES: African-German Network of Excellence in Science. But joint or double degree programs in a subject like "education" seem to be rare; only one example of a joint M.A. Degree (120 ECTS) in 'International Education Management': PH Ludwigsburg \& German Arab Master Program Egypt could be found (Schmees, 2014). On the basis of 'lessons learnt' from existing projects the DAAD (2016b) has issued guidelines for potential German actors on how to start HE cooperation with African partners. Total DAAD budget (year 2016): $€ 500.3$ Million; of mixed origin (35\% AA; 25\% BMBF; 10\% BMZ; 21\% EU; 7\% others).

The key agent in "Cultural Diplomacy" is the Auswärtiges Amt (AA), the German Federal Foreign Office, since cultural and educational policies are the 'third pillar' of the official German foreign policy (besides the economic and political pillars). The AA operates via "intermediary organisations" (Mittlerorganisationen), such as Goethe Institutes, the Alexander von Humboldt Organisation and others. In view of HE it needs to be highlighted that a particular "Science Diplomacy" (Außenwissenschaftspoli- 
tik) concerning science \& technology cooperation has explicitly been defined as part of the German cultural and educational diplomacy since 2009 (Rennkamp \& Seabra, 2009). Examples for financial flows are: 7.1 Mio. Euros subsidies for the education system of Ethiopia or finances for the Pan-African University amounting to 9 Mio. Euros (2011-2016). The total Federal Budget of the AA (year 2017) amounted to € 5,232 Billion.

Allocating HE as a "Trade" to the BMBF (the German Federal Ministry of Education and Research) needs to be explained: Due to Germany being a federal state which grants cultural autonomy (including education) to each member state, the federal ministry of education's influence or interference into the public education systems of its member states is limited and restricted. So the BMBF has to operate in realms which lie 'outside' of the school systems. In its work the BMBF focuses HE as two pillars: (I) scientific research, (II) education in the "tertiary sector" including further \& vocational education which are not part of the 'school system' which at present matches the changing role of HE considering Life Long Learning to be part of the mission of universities today (Field, Schmidt-Hertha \& Waxnegger, 2017). Germany's experience with HE institutions of Applied Sciences (teaching and research for 'practicable' or 'marketable' results) also attracts co- operation with German and African industries, firms and corporations. It should be noted that the BMBF budget for Africa has increased from 12 million Euros (2005) to 58 million Euros (2015) (BMBF, 2017a). In 2001, the BMBF had started a programme called iMOVE (International Marketing of Vocational Education) with the Motto "Training - Made in Germany" in order to sponsor and monitor German education enterprises venturing overseas (Adick, 2014). In the meantime iMOVE has been moved to the BIBB (Federal Institute for
Vocational Education and Training), but still operates under the auspices of the BMBF to facilitate German exports of postsecondary - vocational and technical education. It issues market studies addressed to potential German education providers interested in - among many other countries - Egypt, Kenya, South Africa and Tunisia in Africa (https://www. imove-germany.de) as well as 'success stories' of German partners in Africa, some of which fall into the category of HE, like a commercial ( $€ 7.500$ fees) joint MBA programme of the Frankfurt School of Finance and Management and the Protestant University of Kinshasa (BIBB/iMOVE 2014, p . 18f.). But the BMBF also dispatches "Science Representatives" (Wissenschaftsreferenten) to the German Embassies, which allocates it also to the fields of 'Cultural Diplomacy' meaning that not all its activities may be classified as 'trade'. The total Federal Budget of BMBF (year 2017) was € 17.6 Billion.

Since the year 2000 there have been various DAAD programmes to further German entrepreneurial HE transfers, which makes the DAAD another player in 'trade', an outstanding example being the above-mentioned German University of Cairo (Adick, 2014). Support for HE business across borders also comes from economic policy talk on the global science system (Weltwissenschaftssystem) demanding (more) transnational HE of German providers (vbw - Vereinigung der Bayrischen Wirtschaft, 2012, p. 25 ff., p. 10). Furthermore, it should not be forgotten, that education as an 'export' product also includes the pro-active 'import' of foreign students, especially so if foreign students have to pay university fees like in most such students 'importing' countries like Australia, Great Britain and USA (not - yet? - so in Germany) but in any case regarding the expenses for their living that international students pay in their host country. Germany is also keen of

\begin{tabular}{|c|c|c|c|c|}
\hline & Aid & Exchange & Cultural Diplomacy & Trade \\
\hline Logic & $\begin{array}{l}\text { donor-recipient } \\
\text { relations } \\
\text { dependence }\end{array}$ & $\begin{array}{l}\text { reciprocal relations } \\
\text { symmetric } \\
\text { communication }\end{array}$ & $\begin{array}{l}\text { Part of foreign policy } \\
\text { nation-branding }\end{array}$ & $\begin{array}{l}\text { entrepreneurial } \\
\text { relations across } \\
\text { national borders } \\
\text { (non-profit or } \\
\text { profit-oriented/fully } \\
\text { commercial) }\end{array}$ \\
\hline Actors & $\begin{array}{l}\text { NGOs, religious or } \\
\text { philanthropic } \\
\text { organizations } \\
\text { (mostly co-financed } \\
\text { by state agencies) }\end{array}$ & $\begin{array}{l}\text { Educational and } \\
\text { scientific organiza- } \\
\text { tions (partly state } \\
\text { co-financed) }\end{array}$ & $\begin{array}{l}\text { The foreign office/ } \\
\text { ministry and its } \\
\text { cultural broker org. } \\
\text { (financed by the } \\
\text { state) }\end{array}$ & $\begin{array}{l}\text { Entreprises } \\
\text { (often/or initially } \\
\text { co-financed by state } \\
\text { agencies) }\end{array}$ \\
\hline $\begin{array}{l}\text { Leading German } \\
\text { Governmental } \\
\text { Institutions acting in } \\
\text { HE in Africa }\end{array}$ & $\begin{array}{l}\text { BMZ } \\
\text { (German Federal } \\
\text { Ministry of Coope- } \\
\text { ration \& Develop- } \\
\text { ment) \& BMBF }\end{array}$ & $\begin{array}{l}\text { DAAD } \\
\text { (German Academic } \\
\text { Exchange Service) }\end{array}$ & $\begin{array}{l}\text { AA } \\
\text { (German Federal } \\
\text { Foreign Office) }\end{array}$ & $\begin{array}{l}\text { BMBF } \\
\text { (German Federal } \\
\text { Ministry for Educati- } \\
\text { on and Research) } \\
\text { \& DAAD }\end{array}$ \\
\hline
\end{tabular}


attracting international students, but one has to look which countries are considered promising (and which obviously not). GATE Germany (https://www.gate-germany.de), a consortium by German HE institutions which was established in 2001, still operates under the DAAD and supports German HE institutions in marketing their presence overseas. GATE Germany also issues market studies of potentially attractive countries for German HE exports (African countries: Egypt, Tunisia, Kenya and South Africa). The German model of dual training systems in vocational education - i.e. mixing in-company and part-time school teaching - which is known to be a popular model in German 'development aid' around the world, does to some extent also exist in the HE scenery in Germany, and - is discussed for its potential value in German HE exports (Maschke, 2015). A new partnership programme "Entrepreneurial Universities in Africa" (EpU) which the DAAD started in 2018 with first venues in Kenya, Tunisia and Morocco points into the same direction.

\section{Conclusions and open questions}

The institutions and programmes referred to above are far from exhaustive. They are all to a larger or lesser extent government-backed either in the sense of having originated from and being practically completely run by government institutions (or their 'intermediaries' like the Goethe Institute or the Alexander von Humboldt Foundation), or being sponsored or heavily co-financed by government incentives. In this perspective, then, we can call them the 'official' German policies towards higher education in Africa.

Motives for these connections are varied and not always outspoken. Ubiquitous terms like 'cooperation' or 'partnerships' stand for widely different forms of contacts and connections and often obfuscate intentions and realities behind the curtains which calls for more precise analysis such as the variations of 'aid', 'exchange', 'cultural diplomacy' or 'trade' depicted in this article. As it seems, the main actors tend to serve a variety of motives at the same time, even applying similar techniques such as market studies for German education exports (iMOVE and GATE Germany) and often working together or perhaps at times even competing for the same projects. It is not easy, thus, to determine the overall objectives of German HE transfer to Africa. Is it in the name of mutual exchange with African colleagues or meant as assistance for the still 'underdeveloped' higher education sector in Africa? Or does it want to further nation-branding (upholding the notion of 'made in Germany') or Germany's continuing success as an 'export nation' on the world market? But which types and motives ever, German and African actors' status as basically unequal partners still remains a fact. Who has ever heard of an African enterprise which offers university courses in Germany? Or seen an African country operating for instance a Swahili Institute in Berlin? Or has found Africa sending consultants to European ministries? From this follows the need to consider the underlying power imbalance in whatever variation of 'cooperation' or 'partnership'.

The real outcomes and impact of many programmes would need more scientific research and debate. What has been intended and proclaimed might not come true. Unintended consequences might appear, or things that have been kept obfuscated come to the surface. For example enhancing academic institution-building in Africa with German finances devoted to development cooperation ('aid') might turn out to 'produce' qualified African personnel who are then, intentionally or not, 'drained' towards needy sectors of the German job market. Instructing technicians, nurses, doctors, and others, in Africa by means of German 'development aid' may thus turn out to be less costly than to finance respective higher education training in Germany, be it for Germans or for international students. But where are such implications openly discussed?

The article highlighted the German case (only). This means, a comprehensive analysis of the role of foreign actors in $\mathrm{HE}$ in Africa needs to include more perspectives which have not been discussed in this article: First, the perspectives of African actors who are by far not only by-standing, because speaking of basically unequal partners does not mean complete powerlessness. African politicians, professionals, scientists, parents and others are the ones who choose or reject external 'partners' for 'cooperation' along with their own considerations and criteria of who is found apt for what, whereby it would also be naive to suggest that all African actors' motives were always alike. Second, there are other foreign actors in HE fields in Africa who are also offering models and programmes of $\mathrm{HE}$ with their own aid, trade, exchange, diplomatic or other objectives. Parts of them are run or subsidised by foreign states (like the UK, USA, Australia), others stem from philanthropic foundations (e.g. those of Bill \& Melinda Gates or George Soros) or from enterprises, churches or NGOs. In discussions about relations between Europe and Africa foreign actors are often classified as belonging to 'the global North' vs. 'the global South'. But appealing as this seems to be at first sight, it might be misleading in the long run, since external HE providers from anywhere should better be evaluated according to their objectives and practices instead of their national or regional origin only.

\section{Notes}

1 The article is based on my paper given at the international conference „African Connections" by the African Studies Association in Germany (VAD) at Leipzig University, in June 2018 in a panel which was explicitly directed to: (a) contemporary examples of cooperation (b) between German and African institutions in respect to higher education especially focusing on (c) 'official' German organisations (co-)financed by state budgets.

2 The interviewees with counterparts in Latin America, North America and Asia found rankings most important, but (still?) less so the few interviewees (only 4 out of a total N=56) with counterparts from Sub-Sahara Africa.

3 For a critical appraisal of this organisation and rankings by popularity see Maslen 2010 ; in the meantime, however, the organisation has changed some of its procedures.

4 uniRank $^{\mathrm{Tm}}$ also offers lists by country. Taking the example of Ghana, the first places in this country are occupied by (1) University of Ghana (Legon), (2) Kwame Nkrumah University of Science and Technology (Kumasi), (3) University of Cape Coast Cape Coast), and (4) University of Education Winneba (Winneba); https://www.4icu.org/gh/, accessed 16.02.2018.

5 Besides the governmental institutions discussed in this article there are other German actors who run programmes concerning higher education in Africa and which would therefore need to be considered for a full picture of German relations with higher education in various African countries. Among non-state actors the Volkswagen Foundation's long-term "Knowledge for Tomorrow. Cooperative Research Projects in Sub-Saharan Africa" established in 2003 should be noted, as well as scholarship and other programs of the Churches and non-governmental organisations. 


\section{References}

Adick, C. (1989). Africanization or Modernization? Historical Origins of Modern Academical Education in African Initiative. Liberia-Forum 5(8), 50-62.

Adick, C. (2008). Transnationale Bildungsorganisationen in transnationalen Bildungsräumen: Begriffsdefinitionen und Vorschlag für eine Typologie. Tertium Comparationis, 14(2), 168-197.

Adick, C. (2014): Deutschland als Bildungsexportland. Zeitschrift für Pädagogik, 60(5), 744-763.

Adick, C. (2016). German Foreign Cultural and Educational Policy as a Means of Soft Power. Hungarian Educational Research Journal, 6(3), 11-22. [doi: 10.14413/herj.2016.03.02.]

Adick, C. (2018a). Transnational education in schools, universities, and beyond: definitions and research areas. Transnational Social Review - A Social Work Journal, 8(2), 124-138. [https://doi.org/10.1080/21931674.2018.1463057]

Adick, C. (2018b): Die Bildungsagenda der Vereinten Nationen aus dem Blickwinkel der internationalen Bildungsforschung. Zeitschrift für internationale Bildungsforschung und Entwicklungspädagogik, 41 (2), 11-18.

BIBB/iMOVE (2014): Developung Skills for Employability with German Partners, 8 Success Stories from Sub-Saharan Africa. Bonn.

BMBF (2017a): Die Afrika-Strategie 2014-2018. Afrika als Partner in Bildung und Forschung. Berlin.

BMBF (2017b): Forschungskolleg "Nachhaltiges Regieren" entsteht in Ghana. BMBF Pressemitteilung 124/2017 vom 20.10.2017 Access on 16.04.2019 https://www.bmbf. de/de/forschungskolleg-nachhaltiges-regieren-entsteht-in-ghana-5009.html

BMBF (2018): Creating Prospects!' New Impetus for Cooperation with Africa Partners in Education, Science and Research. Berlin.

BMZ (2014): The BMZ's New Africa Policy. From a continent of crises to one of opportunities. Bonn.

BMZ (2015): BMZ Education Strategy. Creating equitable opportunities for quality education. Bonn.

Burkart, S. \& Wittersheim, U. (2017). Bedeutung internationaler Rankings für die Rekrutierung von Studierenden und für Hochschulkooperationen. Ergebnisse einer DAAD-Umfrage. In GATE Germany (ed.), Internationale Hochschulrankings und ihre Bedeutung für das Hochschulmarketing (pp. 71-93). Bonn: DAAD.

DAAD (2016a): Wissenschaft weltoffen. Access on 16.04.2019 https://www.daad.de/ medien/der-daad/medien-publikationen/publikationen-pdfs/wiwe_2016.pdf

DAAD (2016b): Gemeinsam tragfähige Strukturen entwickeln. Deutsch-Afrikanische Hochschulkooperationen. Bonn.
Feyen, B. \& Krzaklewska, E. (2013). The ERASMUS Phenomenon - Symbol of a New European Generation? Frankfurt: Peter Lang.

Field, J., Schmidt-Hertha, B. \& Waxenegger, A. (eds.) (2017). Universities and Engagement: International perspectives on higher education and lifelong learning. Abingdon: Routledge.

Maschke, K. (2015). Das duale Studium als Exportmodell. DAAD Blickpunkt Nov 2015 Access on 27.03.2019 https://www.daad.de/medien/der-daad/analysen-studien/final_blickpunkt_duales_studium.pdf

Maslen, G. (2010). GLOBAL: Ranking universities by web popularity. Access on 17.02.2018 http://www.universityworldnews.com/article.php?story=2010020511- 2802880

Melber, H. (ed.) (2016). The Rise of Africa's Middle Class. Myths, Realities and Critical Engagements. London: ZED Books.

Rennkamp, B. \& Seabra, A. (2009). Wissenschaftsdiplomatie für eine nachhaltige Entwicklung: Eine Perspektive des Südens. Access on 27.03.2019 https://www. die-gdi.de/uploads/media/Kolumne_Rennkamp_Seabra_09.11.2009.pdf

Scheunpflug, A., Wenz, M. \& Wirth, C. (2018). Das finanzielle Profil der deutschen Bildungszusammenarbeit - eine Analyse der Normen und Realitäten internationaler Bildungspolitik. Zeitschrift für Erziehungswissenschaft. Online First. Access on 16.04.2019 https://link.springer.com/article /10.1007\%2Fs1 1618-018-0843-x [doi:10.1007/s11618-018-0843-x]

Schmees, J. K. (2014). Erziehungswissenschaftliche Masterprogramme mi Double und Joint Degree. Erziehungswissenschaft, 25(48), 143-146.

UNESCO (2017). Six ways to ensure higher education leaves no one behind (Policy Paper 30). Access on 26.03.2019 https://unesdoc.unesco.org/ ark:/48223/pf0000247862

Vbw - Vereinigung der Bayerischen Wirtschaft e.V. (2012). Internationalisie rung der Hochschulen. Eine institutionelle Gesamtstrategie. Gutachten des Aktionsrats Bildung. Münster: Waxmann.

\section{Prof. Dr. Christel Adick}

Chair of Comparative Education at the Ruhr-University Bochum (Germany) from 1993 until her retirement (2013). Dr. phil. University of Hanover; Habilitation University of Siegen. Appointed member of the Editorial Board of the "International Review of Education“ at the UNESCO Institute Hamburg (2000-2010). Main areas of research: Education in the modern world system, education and colonialism (esp. Africa and the Caribbean), international education policy and international education transfer, global education, methodology of international comparative education research. 